\title{
PENERAPAN MODEL PEMBELAJARAN BERBASIS KEARIFAN LOKAL BERORIENTASI KARAKTER TERHADAP KEMAMPUAN MENULIS BERBAHASA INGGRIS MAHASISWA DI IPTS
}

\author{
Oleh : \\ Gabby Maureen Pricilia' ${ }^{1)}$, Habib Rahmansyah ${ }^{2)}$ \\ ${ }^{1}$ Fak. Pend. Ilmu Pengetahuan Sosial dan Bahasa, IPTS \\ ${ }^{1}$ maureenaisyah20@gmail.com \\ ${ }^{2}$ Fak. Pend. Ilmu Pengetahuan Sosial dan Bahasa, IPTS \\ ${ }^{2}$ habib.echo6@gmail.com
}

\begin{abstract}
One of the curriculum's expectations at the fourth semester of english department in Institut Pendidikan Tapanuli Selatan (IPTS) is students are able to write narrative text. But in fact, students' writing narrative text ability is still low, so researcher conduct a research in that field. The purposes of this research are to find out: 1) the extent of students' writing narrative text ability, and 2) the significant effect of using character oriented local wisdom based learning model on students' writing narrative text ability at the fourth semester students of english department in IPTS. The method of research is mix method by combining quantitative and qualitative method. The researcher collected the data by using interview and composition writing test. The sample was taken by using total sampling technique, it was 25 students. The data were then analyzed by using descriptive and inferential analysis, it was t-test formula by Arikunto. The findings of the research are the mean score of students' writing ability before using character oriented local wisdom based learning model was 53.54 which categorized bad, then after using character oriented local wisdom based learning model was 82.50 which categorized good. The hypothesis testing showed that t-test was higher than t-table, it means that the hypothesis is accepted. It clearly seen that there is a significant effect of character oriented local wisdom based learning model on students' writing narrative text ability at the fourth semester students of english department in IPTS.
\end{abstract}

Keywords: Writing Ability, Narrative Text, Local Wisdom, Learning Model

\section{LATAR BELAKANG}

Menulis merupakan salah satu kompetensi mengkomunikasikan ide, informasi, dan juga perasaan dalam bahasa Inggris yang harus dimiliki oleh mahasiswa agar bisa bersaing di derasnya arus globalisasi dewasa ini. Dalam kurikulum bahasa Inggris di tingkat tinggi, mahasiswa diharapkan mampu berkomunikasi dalam bahasa Inggris baik secara lisan maupun tulisan. Sayangnya, tuntutan kurikulum ini belum dapat terelealisasi dengan baik. Kebanyakan mahasiswa mengalami kesulitan dalam menulis bahasa inggris. Hal ini terjadi di Institut Pendidikan Tapanuli Selatan (IPTS) pada mata kuliah menulis (Writing II) yang menunjukkan bahwa kemampuan menulis mahasiswa masih relatif rendah. Hal ini terlihat dari daftar nilai menulis siswa dimana nilai menulis rata-rata belum mampu mendapatkan nilai $B$. Nilai rata-rata mahasiswa dalam menulis adalah 60 dengan kategori nilai C.

Salah satu faktor yang menyebabkan kesulitan siswa menulis dalam bahasa inggris adalah kurang sesuainya model pembelajaran yang digunakan oleh dosen/pengajar. Pengajar memiliki peran penting dalam mensukseskan suatu pembelajaran. Selama ini pengajar seringkali masih menggunakan model pembelajaran konvensional, yang mana dosen yang menjadi pusat proses belajar mengajar (teacher centered) bukanlah berpusat pada siswa (students centered). Hal ini berakibat kurangnya keterlibatan siswa secara aktif di dalam proses pembelajaran sehingga membuat mereka bosan dan tidak tertarik.

Maka pengajar dalam hal ini dosen harus dapat menggunakan model pembelajaran yang sesuai untuk mengajarkan kompetensi menulis. Salah satu model pembelajaran yang ditawarkan untuk mengatasi kesulitan menulis adalah model pembelajaran berbasis kearifan local berorientasi karakter. Kearifan lokal adalah upaya untuk membudayakan nilai-nilai lokal di daerah tempat tinggal mahasiswa misalnya di Padangsidimpuan, Tapanuli Selatan, Panyabungan, dan Tapanuli Tengah. Misalnya Padangsidimpuan, yang merupakan wilayah budaya Angkola yang mengandung nilai-nilai kearifan lokal seperti sistem kekerabatan Dalihan na tolu, dan juga permainan tradisionalnya.

Model ini akan membuat siswa berminat dan menyukai aktifitas menulis karena dekat dengan kehidupan mereka sehari-hari. Sehingga siswa akan semakin dekat dan mencintai budaya lokalnya. Model pembelajaran berbasis kearifan lokal yang digunakan adalah 1) model pembelajaran kelompok dengan sistem kekerabatan Dalihan natolu, berbasis kearifan lokal melalui permainan tradisional, dan 2) melalui cerita rakyat. 
Mengingat arus globalisasi yang tak terbendung, maka dibutuhkan upaya sadar untuk memelihara generasi bangsa dari pergeseran nilainilai budaya lokal oleh budaya asing yang tentu akan berdampak bagi karakter anak bangsa. Pendidikan karakter merupakan kebutuhan yang vital untuk menciptakan manusia yang memiliki integritas nilai-nilai moral yang menjadikan seseorang yang religius, jujur, gotong royong, peduli terhadap lingkungan sekitarnya dalam hal ini termasuk budaya lokalnya.

\section{a. Menulis Narasi}

Nurhadi (2009) menyatakan bahwa menulis adalah aktifitas berpikir yang diwujudkan dalam huruf-huruf yang disusun menjadi suatu kesatuan sehingga memiliki makna. Sebagai keterampilan berbahasa yang dianggap paling sulit, keterampilan menulis mempunyai kedudukan yang sangat penting dan strategis karena dengan menulis, seseorang dapat menyampaikan isi kepala dan hatinya kepada orang lain.

McRobert (1981) juga menyatakan bahwa kesulitan menulis ada pada bagian bagaimana (how) seorang penulis dapat menyampaikan idenya agar dapat dipahami oleh pembaca. Untuk menjadi terampil dalam menulis dibutuhkan latihan yang terus-mnerus. Seperti yang disampaikan oleh Langan (2011) bahwa menulis merupakan keterampilan yang diperoleh dari seringnya latihan sehingga tulisan yang dihasilkan menjadi lebih baik. Artinya semakin sering seseorang menulis maka ia akan semakin terampil dalam menulis.

Menulis narasi bertujuan untuk dapat menghibur pembaca dengan karangan yang dibuat yang mencakup kemampuan menguasai gagasan yang dikemukakan, susunan tulisan, unsur-unsur bahasa, gaya, ejaan serta tanda baca.

Adapun aspek tulisan narasi yang dinilai adalah menurut Hartfield dalam Nurgiyantoro, 2010: 307-308):

1) segi isi yaitu: padat informasi, substantif dan relevan dengan permasalahan

2) segi organisasi yaitu: ekspresi lancar, gagasan diungkapkan dengan jelas, tertata dengan baik, urutan logis dan kohesif

3) segi kosakata yaitu: pemanfaatan potensi kata canggih, pilihan kata tepat dan menguasai pembentukan kata

4) segi penguasaan bahasa yaitu: konstruksi kompleks tapi efektif, penggunaan bentuk kebahasaan, dan

5) segi mekanik yaitu: menguasai ejaan dan aturan penulisan.

\section{b. Model Pembelajaran}

Brady (1985: 7) dalam Aunurrahman (2009: 146) mengemukakan bahwa model pembelajaran adalah blueprint yang dijadikan pedoman pengajar dalam melaksanakan proses pembelajaran.
Sehingga memilih model pembelajaran yang sesuai menjadi salah satu solusi penting untuk mengatasi kesulitan siswa dalam mempelajari bahasa Inggris. Sejalan dengan yang dikatakan oleh Rusman (2012) bahwa bantuan dan bimbingan pendidik sangat dibutuhkan agar dapat mengoptimalkan tujuan pembelajaran.

\section{c. Kearifan Loka}

Kearifan lokal (local wisdom) merupakan pengetahuan lokal seperti sistem kepercayaan, norma, budaya yang digunakan oleh masyarakat lokal untuk dapat bertahan hidup dalam lingkungannya yang regenerasinya disampaikan turun temurun secara lisan.

Sibarani (2012) mengatakan, "Kearifan lokal adalah pengetahuan asli (indigineous knowledge) atau kecerdasan lokal (local genius) suatu masyarakat yang berasal dari nilai luhur tradisi budaya untuk mengatur tatanan kehidupan masyarakat dalam rangka mencapai kemajuan komunitas baik dalam penciptaan kedamaian maupun peningkatan kesejahteraan masyarakat."

Rahyono (2009) menyampaikan bahwa pembelajaran kearifan lokal memiliki 5 fungsi yang strategis sebagai berikut : 1) kearifan lokal sebagai pembentuk identitas, 2) bukan merupakan nilai asing bagi pemiliknya, 3) keterlibatan emosional masyarakat dalam penghayatan kearifan lokal yang kuat, 4) mampu menumbuhkan harga diri, 5) meningkatkan martabat bangsa. Lebih singkat Gunawan (2008) mengatakan bahwa pembelajaran kearifan lokal mempunyai tujuan mendukung siswa untuk aktif, berbudaya, dan mampu bersosialisasi dalam kehidupan bermasyarakat.

Berbicara tentang budaya, kita sudah tahu bahwa Indonesia begitu kaya akan budayanya. Salah satu budayanya adalah budaya yang dimiliki masyarakat Angkola. Masyarakat Angkola memiliki kekayaan budaya yang harus dijaga kelestariannya seperti sistem nilai, budaya dan sosial. Oleh karena itu, diperlukan model pembelajaran yang inovatif untuk mengoptimalkan pembelajaran bahasa Inggris yang tak lepas dari kehidupan nyata mahasiswa, dalam hal ini budaya lokalnya.

\section{d. Pendidikan Karakter}

Fudyartanta (1995: 19) menyatakan bahwa pendidikan budi pekerti adalah penanaman nilainilai yang luhur dan juga baik ke dalam jiwa manusia. Jadi, pendidikan yang berorientasi karakter dapat diartikan sebagai usaha sadar untuk mendidik manusia dalam hal ini siswa agar mampu menggunakan dan mengembangkan fungsi cipta, rasa dan karsanya.

\section{METODE PENELITIAN}

Penelitian ini dilakukan di Institut Pendidikan Tapanuli Selatan yang berlokasi di Jl. Stn. Mhd. Arif Kec. Padangsidimpuan Utara dengan menggunakan metode campuran kualitiatif dan kuantitatif. 
Seluruh siswa semester IV Program Studi Pendidikan Bahasa Inggris menjadi populasi dalam penelitian ini. Ada pun sampel penelitiannya adalah 25 orang mahasiswa yang diambil dengan menggunakan teknik total sampling. Teknik pengumpulan data yang digunakan adalah wawancara, observasi dan tes. Data yang terkumpul kemudian dianalisis menggunakan uji $\mathrm{t}$ menurut Arikunto.

\section{HASIL PENELITIAN DAN}

\section{PEMBAHASAN}

a. Kemampuan Menulis Berbahasa Inggris Mahasiswa sebelum menggunakan Model Pembelajaran Berbasis Kearifan Lokal Berorientasi Karakter terhadap di IPTS

Sebelum menerapkan model pembelajaran berbasis kearifan lokal berorientasi karakter, dilakukan pre-test sebelum diterapkan model pembelajaran tersebut. Dari hasil pretest yang diperoleh, nilai tertinggi 73 dan nilai terendah 27 . Adapun nilai mean 53,54, nilai median 53,89 dan nilai modus 53,84. Untuk lebih jelasnya kemampuan menulis narasi mahasiswa sebelum menggunakan model pembelajaran berbasis kearifan lokal dirincikan pada tabel berikut.

\section{Tabel 3.1 Nilai Mean, Median, Modus sebelum menggunakan}

model pembelajaran berbasis kearifan lokal (Pre-test)

\begin{tabular}{|c|l|c|}
\hline No & \multicolumn{2}{|c|}{ Perolehan Skor Pre-test } \\
\hline 1 & Mean & 53,54 \\
\hline 2 & Median & 53,89 \\
\hline 3 & Modus & 53,84 \\
\hline
\end{tabular}

Selanjutnya deskripsi perolehan nilai menulis narasi berdasarkan indikatornya dideskripsikan sebagai berikut:

1) Kemampuan menulis narasi siswa sebelum menggunakan model pembelajaran berbasis kearifan lokal berorientasi karakter pada indikator isi memperoleh rata-rata 17,16 yang termasuk pada kategori cukup.

2) Kemampuan menulis narasi siswa sebelum menggunakan model pembelajaran berbasis kearifan lokal berorientasi karakter pada indikator organisasi memperoleh rata-rata 16,0 yang termasuk pada kategori cukup baik.

3) Kemampuan menulis narasi siswa sebelum menggunakan model pembelajaran berbasis kearifan lokal berorientasi karakter pada indikator penggunaan kosa kata memperoleh rata-rata 10,64 yang termasuk pada kategori cukup.

4) Kemampuan menulis narasi siswa sebelum menggunakan model pembelajaran berbasis kearifan lokal berorientasi karakter pada indikator tata bahasa memperoleh rata-rata 11,8 yang termasuk pada kategori cukup.
5) Kemampuan menulis narasi siswa sebelum menggunakan model pembelajaran berbasis kearifan lokal berorientasi karakter pada indikator mekanik memperoleh rata-rata 3,08 yang termasuk pada kategori cukup.

Dari deskripsi hasil pretest tersebut jelas bahwa kemampuan menulis narasi bahasa Inggris mahasiswa masih rendah dan oleh sebab itu harus ditingkatkan menjadi lebih baik dengan menggunakan model yang dianggap sesuai yaitu model pembelajaran berbasis kearifan lokal berorintasi karakter.

b. Kemampuan Menulis Berbahasa Inggris Mahasiswa setelah menggunakan Model Pembelajaran Berbasis Kearifan Lokal Berorientasi Karakter terhadap di IPTS

Sebelum model pembelajaran berbasis kearifan lokal berorientasi karakter diaplikasikan, terlebih dahulu dilakukan pretest. Kemudian diperoleh hasil post-test, yang mana nilai tertinggi 89 dan nilai terendah 75. Adapun nilai mean 82 , 54, nilai median 78,5 dan nilai median 77,3 . Untuk lebih jelasnya perolehan skor mean, median, dan modus dirincikan pada tabel berikut.

Tabel 5.3 Nilai Mean, Median, Modus Setelah menggunakan

model pembelajaran berbasis kearifan lokal (Post-test)

\begin{tabular}{|c|l|c|}
\hline No & \multicolumn{2}{|c|}{ Perolehan Skor Post-test } \\
\hline 1 & Mean & 82,54 \\
\hline 2 & Median & 78,5 \\
\hline 3 & Modus & 77,3 \\
\hline
\end{tabular}

Selanjutnya penulis akan mendeskripsikan perolehan nilai menulis narasi bahasa Inggris berdasarkan indikatornya sebagai berikut:

1) Kemampuan menulis narasi siswa setelah menggunakan model pembelajaran berbasis kearifan lokal berorientasi karakter pada indikator isi memperoleh rata-rata 26,12 yang termasuk pada kategori cukup baik.

2) Kemampuan menulis narasi siswa setelah menggunakan model pembelajaran berbasis kearifan lokal berorientasi karakter pada indikator organisasi memperoleh rata-rata 17,84 yang termasuk pada kategori sangat baik.

3) Kemampuan menulis narasi siswa setelah menggunakan model pembelajaran berbasis kearifan lokal berorientasi karakter pada indikator penggunaan kosa kata memperoleh rata-rata 16,0 yang termasuk pada kategori cukup baik.

4) Kemampuan menulis narasi siswa setelah menggunakan model pembelajaran berbasis kearifan lokal berorientasi karakter pada indikator tata bahasa memperoleh rata-rata 18,72 yang termasuk pada kategori cukup baik.

5) Kemampuan menulis narasi siswa setelah menggunakan model pembelajaran berbasis kearifan lokal berorientasi karakter pada 
indikator mekanik memperoleh rata-rata 4,0 yang termasuk pada kategori cukup baik.

Berdasarkan deskripsi nilai perolehan masing-masing indikator di atas menunjukkan bahwa perolehan skor indikator tertinggi adalah organisasi/struktur teks dengan predikat sangat baik dan keempat indikator lainnya dengan predikat cukup baik. Perolehan skor menulis narasi bahasa Inggris mahasiswa Institut Pendidikan Tapanuli Selatan mengalami perubahan yang signifikan setelah diajarkan dengan model pembelajaran berbasis kearifan lokal berorientasi karakter.

\section{c. Karakter}

1) Menunjukkan karakter religius dengan cara berdo'a pada saat sebelum dan sesudah pembelajaran sebagai wujud mengamalkan ajaran agama yang dianutnya Belum Terlihat sebesar $80 \%$ dan Mulai Terlihat $20 \%$.

2) Menunjukkan karakter disiplin dengan hadir tepat waktu dalam kelas serta berperilaku tertib pada saat pembelajaran berlangsung Belum Terlihat 40\%, Mulai Terlihat sebesar $40 \%$ dan Mulai Berkembang 20\%.

3) Menunjukkan karakter rasa ingin tahu ketika dosen menyampaikan informasi dan motivasi pada saat proses pembelajaran berlangsung Mulai Terlihat 20\%.

4) Menunjukkan karakter jujur dalam mengumpulkan data untuk menguji hipotesis Mulai Berkembang sebesar 44\%, Mulai Terlihat sebesar $10 \%$, Mulai Berkembang $8 \%$.

5) Menunjukkan karakter bertanggung jawab mengerjakan tugas sesuai dengan tugas masingmasing Belum Terlihat 52\%, Mulai Terlihat $40 \%$ dan Mulai Berkembang $8 \%$.

6) Menunjukkan karakter kerjasama pada saat diskusi kelompok, Belum Terlihat $40 \%$, dan Belum Terlihat $60 \%$.

7) Menunjukkan karakter komunikatif pada saat diskusi kelompok Belum Terlihat $76 \%$ dan Mulai Terlihat 24\%.

Selanjutnya penulis juga mendeskripsikan karakter mahasiswa selama proses pembelajaran berlangsung setelah diterapkan model pembelajaran. Secara rinci, penulis akan menguraikan berdasarkan indikatornya sebagai berikut:

1) Menunjukkan karakter religius dengan cara berdo'a pada saat sebelum dan sesudah pembelajaran sebagai wujud mengamalkan ajaran agama yang dianutnya Menjadi Kebiasaan (Membudaya) sebesar $68 \%$ dan Mulai Berkembang sebesar $64 \%$.

2) Menunjukkan karakter disiplin dengan hadir tepat waktu dalam kelas serta berperilaku tertib pada saat pembelajaran berlangsung Menjadi Kebiasaan (Membudaya) sebesar 44\%, Mulai Berkembang sebesar $44 \%$ dan Mulai Terlihat sebesar $12 \%$.

3) Menunjukkan karakter rasa ingin tahu ketika dosen menyampaikan informasi dan motivasi pada saat proses pembelajaran berlangsung Mulai Berkembang sebesar $84 \%$ dan Menjadi Kebiasaan sebesar $16 \%$.

4) Menunjukkan karakter jujur dalam mengumpulkan data untuk menguji hipotesis Mulai Berkembang sebesar 60\%, Menjadi Kebiasaan (Membudaya) sebesar 24\% dan Mulai Terlihat sebesar 16\%.

5) Menunjukkan karakter bertanggung jawab mengerjakan tugas sesuai dengan tugas masingmasing Menjadi Kebiasaan (Membudaya) sebesar 44\%, Mulai Berkembang sebesar 44\% dan Mulai Terlihat sebesar $12 \%$.

6) Menunjukkan karakter kerjasama pada saat diskusi kelompok, Menjadi Kebiasaan (Membudaya) sebesar 92\% dan Mulai Berkembang sebesar $8 \%$.

7) Menunjukkan karakter komunikatif pada saat diskusi kelompok, Mulai Terlihat 40\%, Menjadi Kebiasaan (Membudaya) sebesar 32\% dan Mulai Berkembang sebesar $28 \%$.

Berdasarkan hasil penelitian di atas, peneliti menemukan adanya dampak yang signifikan dari penggunaan model pembelajaran berbasis kearifan lokal berorientasi karakter. Sebelumnya peneliti telah mengumpulkan data sebelum menerapkan model pembelajaran berbasis kearifan lokal (pretest). Hasilnya menunjukkan bahwa kemampuan menulis narasi berbahasa Inggris mahasiswa di IPTS masih rendah. Namun setelah diterapkan model pembelajaran berbasis kearifan lokal berorientasi karakter, kemampuan menulis narasi berbahasa Inggris mahasiswa mengalami perubahan yang signifikan. Dengan kata lain, hipotesis penelitian diterima yang artinya terdapat dampak yang signifikan dari penggunaan model pembelajaran berbasis kearifan lokal berorientasi karakter terhadap kemampuan menulis berbahasa Inggris mahasiswa di IPTS.

Rendahnya kemampuan menulis narasi berbahasa Inggris mahasiswa sebelumnya disebabkan oleh kurangnya minat dan minimnya pengetahuan mahasiswa dalam menulis narasi bahasa Inggris. Hal tersebut diakibatkan oleh model pembelajaran yang diterapkan selama ini dianggap kurang dalam menumbuhkan minat, semangat dan meningkatkan pengetahuan mahasiswa tentang menulis narasi bahasa inggris tersebut. Sehingga mahasiswa menganggap bahwa menulis narasi dengan menggunakan bahasa Inggris itu sangat sulit dan tidak menarik.

Mengatasi persoalan tersebut peneliti menawarkan solusi model pembelajaran yang dianggap dapat meningkatkan kemampuan menulis narasi berbahasa Inggris mahasiswa. Model pembelajaran berbasis kearifan lokal berorientasi karakter diterapkan untuk meningkatkan kemampuan menulis narasi berbahasa Inggris mahasiswa. Seperti yang telah dijelaskan sebelumnya bahwa model pembelajaran memegang peranan penting dalam mensukseskan 
pembelajaran di kelas, sehingga pengajar harus mampu memilih menggunakan model pembelajaran yang tepat dalam mengajar.

Kearifan lokal merupakan bentuk kebijaksanaan lokal yang mengandung nilai-nilai kebaikan yang diyakini, diterapkan dan terus dijaga keberadaannya dalam kurun waktu yang lama dan diwariskan secara turun temurun dalam wilayah tertentu. Pembelajaran berbasis kearifan lokal yang diterapkan dalam mengajarkan keterampilan menulis narasi berbahasa Inggris mahasiswa di IPTS terbukti dapat meningkatkan kemampuan menulis mahasiswa. Nilai kearifan lokal masyarakat dalam hal ini mahasiswa yang datang dari berbagai daerah di kampus IPTS diadopsi dalam pembelajaran seperti nilai dalam sistem kekerabatan Dalihan na tolu yaitu mora, kahanggi dan anak boru dan permainan tradisional. Hal tersebut menumbuhkan minat mahasiswa karena dekat dengan kehidupan mereka sehari-hari sehingga membuat mahasiswa lebih mudah memahami dan terlibat aktif dalam proses pembelajaran. Dengan begitu, mahasiswa menjadi lebih bersemangat dan fokus dalam belajar sehingga kemampuan menulis narasi berbahasa Inggris mereka meningkat signifikan.

Hal ini sejalan dengan penelitian sebelumnya oleh Mimi Mulyani (2011) dengan judul Model Pembelajaran Menulis Berbasis Kearifan Lokal Berorientasi Karakter (Studi Kuasi Eksperimen pada siswa SMPN 2 Magelang) yang menunjukkan bahwa model pembelajaran berbasis kearifan lokal yang diterapkan untuk mengajarkan keterampilan menulis siswa SMP dapat meningkatkan kemampuan menulis siswa. Hal tersebut disebabkan oleh kearifan lokal mengandung nilai-nilai yang luhur. Dan juga membuat siswa menjadi mudah untuk mendapatkan inspirasi menulis yaitu dari budaya lokalnya sendiri yang sudah dikenali sebelumnya.

Dengan demikian, penerapan model pembelajaran berbasis kearifan lokal berorientasi karakter memberikan dampak yang signifikan terhadap kemampuan menulis narasi berbahasa Inggris mahasiswa di IPTS.

\section{KESIMPULAN}

Setelah menganalisis data sebagai hasil dari penelitian, peneliti membuat kesimpulan sebagai berikut:

a. Kemampuan menulis narasi berbahasa Inggris mahasiswa di IPTS sebelum menggunakan model pembelajaran berbasis kearifan lokal berorientasi karakter adalah 53,54 atau berada pada kategori rendah. Kemudian, kemampuan menulis narasi berbahasa Inggris mahasiswa setelah menggunakan model pembelajaran berbasis kearifan lokal berorientasi karakter adalah 82,54 atau berada pada kategori baik.

b. Terdapat dampak yang signifikan dari penggunaan model pembelajaran berbasis kearifan lokal berorientasi karakter terhadap kemampuan menulis narasi berbahasa Inggris mahasiswa di IPTS yang terlihat dari hasil perhitungan t-hitung lebih besar daripada t-tabel $(17,63>2,06)$. Dengan kata lain, hipotesis penelitian diterima.

\section{REFERENSI}

Arikunto, Suharsimi. 2007. Manajemen Penelitian. Jakarta: Rineke Cipta.

Langan, J. 2011. College Writing Skills with Readings-International Edition 8th Edition. New York: McGraw-Hill, Inc.

Mc Robert, R. 1981. Writing Workshop: A Student's Guide to the Craft of Writing. Australia: The Macmillan Company.

Mulyani, Mimi. 2011. Model Pembelajaran Menulis Berbasis Kearifan Lokal yang Beorientasi Pendidikan Karakter. Jurnal Pena, Vol. 1 No. 1 Desember 2011.

Nurhadi. 2009. Bagaimana Menulis: Handbook of Writing (Modul Perkuliahan). Program Pascasarjana Universitas Negeri Malang.

Nurgiyantoro, Burhan. 2010. Penilaian Pembelajaran Bahasa Berbasis Kompetensi. Yogyakarta: BPFEYogyakarta.

Rusman. 2012. Model-Model Pembelajaran.Mengembangkan Profesionalisme Guru. Edisi kedua. Divisi Buku Perguruan Tinggi. PT Raja Grafindo Persada, Jakarta.

Ruyadi, Yadi. 2010. Model Pendidikan Karakter Berbasis Kearifan Budaya Lokal (Penelitian terhadap Masyarakat Adat Kampung Benda Kerep Cirebon Provinsi Jawa Barat untuk Pengembangan Pendidikan Karakter di Sekolah). Proceedings of The 4 International Conference on Teacher Education; Join Conference UPI \& UPSI Bandung, Indonesia.

Sibarani, R. 2012. Kearifan Lokal, Hakikat, Peran, dan Metode Tradisi Lisan. Jakarta: Asosiasi Tradisi Lisan. 